\title{
When rendering hospitality becomes collateral damage: Psycho-organisational variables and job burnout amongst hotel workers in metropolitan Nigeria
}

\begin{tabular}{|c|c|}
\hline \multicolumn{2}{|c|}{$\begin{array}{l}\text { Authors: } \\
\text { Oluyinka Ojedokun }{ }^{1,2} \\
\text { Erhabor S. Idemudia }^{1} \\
\text { Arike O. Omotoso }{ }^{2}\end{array}$} \\
\hline \multicolumn{2}{|c|}{$\begin{array}{l}\text { Affiliations: } \\
{ }^{1} \text { Department of Psychology, } \\
\text { North-West University, } \\
\text { South Africa }\end{array}$} \\
\hline \multicolumn{2}{|c|}{$\begin{array}{l}\text { ²Department of Pure } \\
\text { and Applied Psychology, } \\
\text { Adekunle Ajasin University, } \\
\text { Nigeria }\end{array}$} \\
\hline \multicolumn{2}{|c|}{$\begin{array}{l}\text { Correspondence to: } \\
\text { Oluyinka Ojedokun }\end{array}$} \\
\hline \multicolumn{2}{|c|}{$\begin{array}{l}\text { Email: } \\
\text { yinkaoje2004@yahoo.com }\end{array}$} \\
\hline \multicolumn{2}{|c|}{$\begin{array}{l}\text { Postal address: } \\
\text { Private Bag X2046, } \\
\text { Mmabatho 2735, } \\
\text { South Africa }\end{array}$} \\
\hline \multicolumn{2}{|c|}{$\begin{array}{l}\text { Dates: } \\
\text { Received: } 09 \text { Apr. } 2013 \\
\text { Accepted: } 25 \text { July } 2013 \\
\text { Published: } 09 \text { Oct. } 2013\end{array}$} \\
\hline \multicolumn{2}{|c|}{$\begin{array}{l}\text { How to cite this article: } \\
\text { Ojedokun, O., Idemudia, E.S., } \\
\text { \& Omotoso, A.O. (2013). } \\
\text { When rendering hospitality } \\
\text { becomes collateral damage: } \\
\text { Psycho-organisational } \\
\text { variables and job burnout } \\
\text { amongst hotel workers } \\
\text { in metropolitan Nigeria. } \\
\text { SA Journal of Industrial } \\
\text { Psychology/SA Tydskrif vir } \\
\text { Bedryfsielkunde, 39(1), Art. } \\
\text { \#1124, } 9 \text { pages. http:// } \\
\text { dx.doi.org/10.4102/sajip. } \\
\text { v39i1.1124 }\end{array}$} \\
\hline \multicolumn{2}{|c|}{$\begin{array}{l}\text { Copyright: } \\
\text { (C) 2013. The Authors. } \\
\text { Licensee: AOSIS } \\
\text { OpenJournals. This work } \\
\text { is licensed under the } \\
\text { Creative Commons } \\
\text { Attribution License. }\end{array}$} \\
\hline \multirow{2}{*}{ Read online: } & \\
\hline & $\begin{array}{l}\text { Scan this QR } \\
\text { code with your } \\
\text { smart phone or } \\
\text { mobile device } \\
\text { to read online. }\end{array}$ \\
\hline
\end{tabular}

Authors:

Erhabor S. Idemudia

O. Omotoso

North-West University,

South Africa

Department of Pure

Adekunle Ajasin University,

Correspondence to:

Oluyinka Ojedokun

Email:

Postal address:

Private Bag X2046

Mmabatho 2735,

Dates:

Received: 09 Apr. 2013

Accepted: 25 July 2013

\& Omotoso, A.O. (2013)

When rendering hospitality

variables and job burnout

mongst hotel workers

SA Journal of Industrial

Psychology/SA Tydskrif vir

Bedryfsielkunde, 39(1), Art.

\#1124, 9 pages. http://

dx.doi.org/10.4102/sajip.

Copyright:

(c) 2013. The Authors

Licensee: AOSIS

OpenJournals. This work

licensed under the

Creative Commons

Attribution License.

code with your

mobile device

to read online.
Orientation: Job burnout is a serious problem in the hospitality industry. Therefore, employees require ongoing job and personal resources to cope with job burnout.

Research purpose: The study investigated the influence of psycho-organisational variables (i.e. perceived organisational support, self-efficacy and age) on job burnout amongst hotel workers.

Motivation for the study: Investigating the independent and joint influence of psychoorganisational variables on burnout will assist in pulling together psycho-organisational factors influencing burnout and its dimensions cohesively in systematic theory building and intervention plans.

Research design, approach and method: This is a cross-sectional survey designed to investigate perceived organisational support, self-efficacy and age as predictors of job burnout amongst 268 hotel workers from 10 registered hotels in some metropolitan cities in Ondo State, south-western Nigeria. Structural equation modelling techniques were conducted to test the proposed hypotheses.

Main findings: Structural equation modelling revealed that perceived organisational support and self-efficacy have inverse relationships with burnout syndrome and its dimensions.

Practical/managerial implications: These findings imply that it is possible for different stakeholders in the hotel industry in Nigeria to reduce the incidence of high burnout amongst hotel workers by providing adequate organisational support to cope with difficult job demands and organising self-efficacy training to improve individuals' confidence in their abilities to deal with job burnout. Such intervention can be individual-oriented, organisation-oriented or a combination.

Contribution/value-add: This study contributes to literature by confirming that organisational support and self-efficacy are relevant in coping with burnout.

\section{Introduction}

Job burnout is a type of job stress in which a 'normal employee' becomes physically, mentally and emotionally exhausted (Leiter, Jackson \& Shaughnessy, 2009; Maslach \& Jackson, 1981). Employees experience burnout after extended periods of high stress in work settings (Heverling, 2011). Workers experiencing burnout have low energy and motivation, experience negative and cynical feelings about themselves or their work, distance themselves from interpersonal interactions and question their career choice and the value of their contribution at work (Maslach, Schaufeli \& Leiter, 2001). When workers experience job burnout, it creates negative effects on their physical and psychological health, job performance and productivity, as well as frequent visits to hospital, increased absenteeism and turnover (Lee \& Shin, 2005; Maslach et al., 2001).

Research in Nigeria has shown that there is an increased risk of burnout amongst hotel workers (e.g. Karatepe \& Aleshinloye, 2009; Karatepe \& Olugbade, 2009). This observation is consistent with other studies done amongst hotel employees in the United States (Kang, Twigg \& Hertzman, 2010; O'Neil \& Xiao, 2010) and Korea (Lee, 2011). The Permanent Life Situation Survey (2009) indicated that hotel and restaurant workers experience burnout at a rate of one in seven. This may be because of the 24/7 nature of the hotel business: workers render services in an environment that is full of challenges, pressures and demands that can become sources of stress. Such a work situation can be found in the restaurant, hotel and airline industries (Bitner, Booms \& Mohr, 1994; Ledgerwood, Crotts \& Everett, 1998). Accumulated stress increases the likelihood of burnout. Therefore, understanding the personal and organisational factors that may help employees to cope with the risk of burnout will aid in the development of strategies that individuals and management can use to manage and reduce burnout effectively. 
Burnout, a state of vital exhaustion, is a psychological construct classified under problems related to life management difficulty by international classification of diseases and related health problems (World Health Organization [WHO], 2010). So far in Nigeria, research on burnout in hotel workers is dominated by experts in hospitality management; these studies were undertaken only in five-star and fourstar hotels in Abuja and Lagos (e.g. Karatepe \& Aleshinloye, 2009; Karatepe \& Olugbade, 2009). The concern here is that environmental variations may limit the generalisation of the findings of these studies beyond these two settings.

Karatepe and Aleshinloye (2009) used the conservation of resources (COR) theory (Hobfoll, 1989) to explain relationships amongst negative affectivity, intrinsic motivation, emotional dissonance and emotional exhaustion; Karatepe and Olugbade (2009) adopted the job demandsresources (JD-R) model (Bakker \& Demerouti, 2007; Demerouti, Bakker, Nachreiner \& Schaufeli, 2001) and COR theory to explain the relationships amongst competitiveness, self-efficacy, supervisor support and work engagement. However, these studies did not consider the joint influence of perceived organisational support and self-efficacy as predictors of job burnout amongst hotel workers.

Hence, a gap exists in literature. Incorporating the joint influence of job resources and personal resources into the JD-R and COR models will assist in pulling together the psycho-organisational factors influencing total burnout and its dimensions cohesively in systematic theory building.

Karatepe and Aleshinloye (2009) limited their investigation of burnout to emotional exhaustion. Yet burnout is a syndrome of emotional exhaustion, depersonalisation and decreased personal accomplishment. If research into burnout focuses on the exhaustion component only, researchers may lose sight of the phenomenon entirely (Jackson, Schwab \& Schuler, 1986). Hence there is a paucity of research that investigates the influence of perceived organisational support and selfefficacy on all dimensions of burnout amongst hotel workers.

\section{Research objectives}

The purpose of this study is to determine whether perceived organisational support, self-efficacy and age are predictors of job burnout amongst hotel workers in some metropolitan cities in Ondo State, south-western Nigeria.

Accordingly, the study has two specific objectives:

- To investigate the independent influence of perceived organisational support, self-efficacy and age on job burnout and its three dimensions (emotional exhaustion, depersonalisation and decreased personal accomplishment)

- To investigate the joint influence of perceived organisational support, self-efficacy and age on job burnout and its three dimensions (emotional exhaustion, depersonalisation and decreased personal accomplishment).
It is hoped that the outcome of this study will benefit both hotel managers and employees. When burnout is handled properly and workers are at their full potential, both hotels and employees reap the rewards. The hotels will have staff that work at full capacity to best serve the guests. Workers are also more likely to achieve their career goals and be productive.

In the subsequent sections of the paper, the theoretical background, definitions of concepts and hypotheses to be tested will be outlined and the research design, including the research approach and methods, will be specified. The researchers then present the results from the data analysis and these are discussed in the light of relevant literature. The paper ends with conclusion and limitations of study.

\section{Theoretical rationale and hypotheses}

Personal observation of the researchers and in-depth interaction with some hotel employees and their supervisors revealed that hotel workers in Nigeria render their services in a stressful environment. This environment is a precursor of burnout. In Nigeria, power outage is rampant; there is a high level of unemployment, resulting in casualisation of both skilled and unskilled workers. Most of the operations in Nigerian hotels are manualised. Hotel workers are from vulnerable groups, due to low entry qualifications, and there is no wellness package in place for the workers. These poor environmental conditions expose them to high level of stress that can make them more vulnerable to burnout. Hence, working in the Nigerian hotels may actually cause collateral damage to psychological and physical well-being of employees. Hence, hotel employees require ongoing organisational and individual resources to cope with jobrelated stress and to prevent burnout. To this end, three psycho-organisational variables (perceived organisational support, self-efficacy and age) were selected for study as predictors of burnout. Based on JD-R and COR (Bakker \& Demerouti, 2007; Demerouti et al., 2001; Hobfoll, 1989), these variables are well documented as highly predictive of burnout.

Attempts to relate psycho-organisational factors to employee well-being in psychology have produced some theories which are relevant to explaining job burnout. The first is the job demands-resources (JD-R) model (Bakker \& Demerouti, 2007; Demerourti et al., 2001), which considers both the job demands and job resources aspects of a work context and their links to the emergence of burnout. Job demands are job aspects that require sustained physical and/or psychological (cognitive and emotional) effort and therefore lead to the depletion of energy and to health problems (Thomas \& Lankau, 2009). Job resources are physical, psychological, social or organisational aspects of the job that are functional in achieving work goals, reducing job demands and the associated physiological and psychological costs and stimulating personal growth, learning and development. Resources may be located at the level of the organisation (e.g. salary, career opportunities, job security), interpersonal and 
social relations (e.g. perceived organisational support), work organisation (e.g. role clarity) or task (e.g. job characteristics). Job resources are considered to enhance employees' wellbeing, that is, they are assumed to prevent burnout. Studies (e.g. Bakker, Demerouti \& Verbeke, 2004; Hakanen, Bakker \& Schaufeli, 2006) have found that job resources are negatively related to exhaustion and cynicism, and positively related to personal accomplishment.

In Nigeria, Adebayo and Ezeanya (2011) conceptualised their study within the JD-R theory to investigate task identity and job autonomy as correlates of burnout amongst nurses. They found that task identity $(r=-0.59 ; p<.01)$ and job autonomy $(r=-0.46 ; p<.01)$ have negative significant correlations with burnout. In a South African study by De Beer, Pienaar and Rothmann (2013) that adopted the JD-R model to investigate the reversed causality of engagement and burnout in JD-R theory, it was reported that burnout has a significant negative longitudinal relationship with colleague and supervisor support, with the prominent influence attributed to supervisor support over time. In another study in the United States of America by Lizano and Mor Barak (2012) contextualised within the JD-R model to investigate the influence of job stress, work-family conflict, organisational support and supervisory support on job burnout amongst public child welfare workers, it was found that tenure, job stress and work-family conflict were associated with the development of emotional exhaustion, whilst age, workfamily conflict and organisational support were related to the development of depersonalisation.

A second theory is the conservation of resources (COR) theory, which contends that individuals strive to gain personal resources, either instrumental (e.g. money, insurance or shelter), social (e.g. secure job, healthy marriage, social support or status) or psychological (e.g. self-efficacy, self-esteem or sense of autonomy). Stressful or traumatic events consume resources, thereby augmenting individual sensitivity to subsequent stressors (Hobfoll \& Lilly, 1993). The COR theory suggests that people work to acquire resources that they do not have, preserve those resources they have, protect resources when they are threatened and cultivate resources by positioning themselves so that they can use resources to accommodate, withstand or overcome threats. Therefore, those with greater resources are less vulnerable to resource loss and more capable of orchestrating resource gain, whereas, for those with fewer resources, ongoing resource loss may result in a rapid influential loss spiral (Hobfoll, 2002).

Using COR theory as their theoretical approach, Karatepe and Aleshinloye (2009) studied negative affectivity, intrinsic motivation, emotional dissonance and emotional exhaustion amongst hotel employees in Nigeria, and reported that emotional dissonance partially mediated the relationships of negative affectivity and intrinsic motivation with emotional exhaustion. Adopting both JR-D and COR theories, Karatepe and Olugbade (2009) examined the effects of job (supervisory support) and personal (trait competitiveness and selfefficacy) resources on hotel employees' work engagement in Nigeria. They found that trait competitiveness predicted three dimensions of work engagement better than selfefficacy. They also reported that supervisory support had no significant effects on the three dimensions of work engagement.

The summary from the JD-R model and the COR theory is that burnout is a consequence of too many job demands and low job resources to deal with the demands. Also, lack of personal resources to cope with job demands play a role in the process of burnout, and to some extent these factors can be used to identify individuals who may be at increased risk of burnout. That is, individuals are vulnerable to burnout when they lack personal resources (e.g. low self-efficacy) and job resources (e.g. organisational support) to enlist in coping with high job demands.

Perception of organisational support (POS) is a job resource (Hobfoll, 1989) that enhances employees' confidence in their ability to cope with job demands (Lazarus, 1991). POS refers to employees' perception concerning the extent to which the organisation values their contribution and cares about their well-being (Eisenberger, Huntington, Hutchison \& Sowa, 1986; Rhoades \& Eisenberger, 2002). Workers who perceive high levels of POS are less likely to experience burnout because organisations that care about their employees' well-being are more likely to reduce unnecessary work complications for their workers. Based on this discussion, it is logical to expect that differences in perception of organisational support will affect hotel workers' burnout perception differently. Studies (e.g. Carlson \& Perrewe, 1999; Parasuraman, Greenhaus \& Granrose, 1992) have reiterated that social support reduces the negative effects of role stressors by helping employees to cope with stress. Similarly, Brotheridge and Lee (2005) have implicated co-worker or supervisor support but not POS in the role stress reduction process, as well as in buffering the negative consequences of role stress. In contrast, findings established relationships between increased levels of POS and a sense of accomplishment and contribution (Jain \& Sinha, 2005), decreased somatic complaints (Dupre \& Day, 2007), and decreased burnout (Humborstad, Humborstad \& Whitfield, 2008; Kang et al., 2010). Hence, POS appears to have an influence on burnout.

Self-efficacy refers to an individual's socially acquired, cognitive expectancies of being able to enact successfully specific actions that are required to reach a desired end state (Bandura, 1997). Self-efficacy in this study refers to hotel workers' beliefs that they have knowledge and competencies to deal with pressure and job demands associated with working in a hotel. According to social cognitive theory (Bandura, 1986), self-efficacy makes a difference to how people think, feel and act. In terms of feeling, a low sense of self-efficacy is associated with depression, anxiety and helplessness. In terms of thinking, a strong sense of competence facilitates cognitive processes and a specific 
way of viewing and approaching problems. In terms of acting, people with high self-efficacy choose to perform more challenging tasks (Bandura, 1997; Schwarzer, 1992). They set higher goals for themselves, and stick to them. The construct of self-efficacy suggests a protective effect when coping with adversity. An optimistic belief in one's competence to deal with daily challenges enhances the motivation to engage in constructive ways of coping. Thus, self-efficacious hotel workers, compared with those who harbour self-doubts, would strive to master their job demands and perceive them as less threatening, thereby preventing burnout. Successful adaptation to stressful demands is believed to prevent the emergence of job burnout (Caprara, Barbaranelli, Borgogni \& Steca 2003; Skaalvik \& Skaalvik, 2007). Studies have established that personality traits make a difference in handling burnout (Maslach et al., 2001; Schaufeli \& Enzmann, 1998).

Findings linking age to burnout are inconclusive. Melendez and deGuzman (1983) found that age was related to burnout due to mid-life crisis. Maslach et al. (2001) reported that the rate of younger employees' burnout is greater than those employees who are in their 30s or 40s. However, Hughes (1995) found that individuals at risk for burnout were those in the $45-55$ years of age category.

Essentially, an emerging trend in literature is the examination of the joint influence of environmental and personal factors in the burnout process (Burisch, 2002, Peiro, 1993). Representative of this perspective are Bakker and Schaufeli (see Bakker, Demerouti \& Schaufeli, 2003). It is in this light that this study hypothesises that: (1) perceived organisational support, self-efficacy and age will independently contribute to total burnout and its three dimensions, and (2) perceived organisational support, self-efficacy and age will contribute jointly to total burnout and its three dimensions.

\section{Research design \\ Research approach}

The study adopted a cross-sectional quantitative survey design. The independent variables are perceived organisational support, self-efficacy and age. The dependent variable is job burnout. The three dimensions of burnout were examined separately.

The study took place in Ondo State, Nigeria, using four study sites: Akure, Ondo, Ore and Owo, purposely selected because of their metropolitan nature. Ondo State, with Akure as the state capital, was created on 03 February 1976 from the former Western State. It originally included what is now Ekiti State, which was split off in 1996. The state is one of the states in the south-western region of Nigeria. It has a population of 3441024 million people (National Population Commission of Nigeria). The state contains eighteen local government areas. The majority of the state's citizens live in urban centres. The state boasts some tourist attractions such as Idanre hills, Owo Museum of Antiquities, Igbo Olodumare, Igbo Irunmole,
Cave of Ashes, Isarun, Palace of The Deji of Akure, Ebomi Lake, Coast Creek and Canal and Oke Maria. Visitor flow into the state is quite high, cutting across all social strata.

\section{Research method}

\section{Participants}

The research population for the study was defined as all hotel workers in Ondo State, Nigeria. Through purposive, opportunistic and convenience sampling methods, 268 employees (136 men, 59.75\% and 132 women, 49.25\%) sampled from 10 registered hotels participated in the study. All together, the 10 hotels employed a total of 416 workers. These hotels range in size from 75-145 rooms. The participants' ages range between 19 and 52 years $(\mathrm{M}=30$; $\mathrm{SD}=6.53)$. In terms of marital status, 140 were single $(52.2 \%)$, 115 were married $(42.9 \%)$ and 13 were divorced or separated (4.9\%). The participants indicated their educational level as primary school $(18,6.7 \%)$, secondary school $(53,19.8 \%)$, diploma/college $(112,41.8 \%)$ or university $(72,26.9 \%)$. In term of positions, there were 20 receptionists $(7.5 \%), 27$ accounting officers $(10.1 \%), 21$ cooks $(7.8 \%), 25$ bartenders (9.3\%), 47 food servers (28.5\%), 10 drivers (3.7\%), 15 security workers $(5.6 \%), 15$ maintenance officers $(5.6 \%), 26$ room cleaners $(9.7 \%), 15$ bell attendants (5.6\%), 14 supervisors (5.2\%), 17 porters $(6.3 \%)$ and 16 guest relation representatives $(6.0 \%)$. All ethical guidelines in the treatment of human participants in the research were observed during this study. Table 1 presents the demographic characteristics of the participants.

\begin{tabular}{|c|c|c|}
\hline Category & $f$ & $\%$ \\
\hline \multicolumn{3}{|l|}{ Gender } \\
\hline Male & 136 & 59.75 \\
\hline Female & 132 & 49.25 \\
\hline \multicolumn{3}{|l|}{ Marital status } \\
\hline Single & 140 & 52.20 \\
\hline Married & 115 & 42.90 \\
\hline Divorced & 13 & 4.90 \\
\hline \multicolumn{3}{|l|}{ Highest education } \\
\hline Primary school & 18 & 6.70 \\
\hline Secondary school & 53 & 19.80 \\
\hline Polytechnic/college & 112 & 41.80 \\
\hline University & 72 & 26.90 \\
\hline \multicolumn{3}{|l|}{ Position } \\
\hline Receptionist & 20 & 7.50 \\
\hline Accounting officer & 27 & 10.10 \\
\hline Cook & 21 & 7.80 \\
\hline Bartender & 25 & 9.30 \\
\hline Food server & 47 & 28.50 \\
\hline Driver & 10 & 3.70 \\
\hline Security worker & 15 & 5.60 \\
\hline Maintenance officer & 15 & 5.60 \\
\hline Room cleaner & 26 & 9.70 \\
\hline Bell attendant & 15 & 5.60 \\
\hline Supervisor & 14 & 5.20 \\
\hline Porter & 17 & 6.30 \\
\hline Guest relation representative & 16 & 6.00 \\
\hline
\end{tabular}

$f$, frequency. 


\section{Measures}

Background information of age, gender, level of education, marital status and job position were obtained in addition to measures of perceived organisational support, self-efficacy and burnout. The items in each of the constructs were taken from different sources in the extant literature.

Perceived organisational support: This is a 17-item scale developed by Eisenberger et al. (1986). The scale assesses workers' evaluations of organisational issues that affect their well-being. Sample items include 'The organisation values my contribution to its well-being' and 'The organisation takes pride in my accomplishments'. Participants responded on a five-point scale ranging from not at all (1) to very much (5). Shore and Wayne (1993) reported a coefficient alpha of .95 for this scale. Ojedokun (2010) established a coefficient alpha of .77 for the scale amongst bank workers in Nigeria. A coefficient alpha score of .71 was obtained amongst the present sample.

Self-efficacy: This was measured with a 10-item general self-efficacy scale (SES) (Schwarzer \& Jerusalem, 1995). The scale measures the extent to which an individual is able to cope when confronted with difficulties or problem. SES was scored on a four-point scale: not at all true (1) to exactly true (4). Sampled item include 'I can always manage to solve difficult problems if I try enough'. The high reliability (alphas ranging from .76 to .90 ) of the scale has been demonstrated across various research contexts and diverse populations (e.g. Luszczynska, Scholz \& Schwarzer, 2005). Babalola (2009) reported a Cronbach alpha of 89 for the scale amongst women entrepreneurs in Nigeria. The Cronbach alpha for the scale in the present study was .72.

Burnout: To assess burnout and its dimensions, the Maslach Burnout Inventory (MBI; Maslach, Jackson, \& Leiter, 1996) was administered. This measures emotional exhaustion (EE) with nine items, such as 'I feel emotionally drained from my work', depersonalisation (DP) with five items, such as 'I feel I treat some customers/lodgers as if they were impersonal objects', and personal accomplishment (PA) with eight items, such as 'I have not attained important goals with my work'. All items use a seven-point scale, from never (0) to every day (6), indicating the frequency of a feeling or perception. The first two scales (EE \& DP) are scored so that higher scores indicate greater problems with burnout. In its typical form, the PA scale is scored in the direction of lower scores indicating greater levels of burnout. Because the current investigators wanted to be able to develop a total score for burnout, the PA scale scoring procedure was altered. Consequently, all items were reversed scored on the PA scale; thus, the direction of the PA score and its interpretation were reversed. In this altered scoring format, higher PA scores indicate higher levels of burnout. Higher scores are then interpreted as indicating low levels of personal accomplishment, associated with higher levels of burnout. Further, all items that met the criteria of $r=0.40 ; p<.05$ from the three sub-scales were then added together to obtain a total burnout score, although the use of a burnout total score was not recommended in the MBI manual. However, to increase the stability of parameter estimates, SEM researchers (e.g. Blunch, 2013) suggest parcelling scale items if items have large variance, the same numerical magnitude, positive correlations and all items correlate with the sum of the rest. All of these conditions were adhered to in the study. According to the MBI manual, the scales have acceptable levels of reliability (Maslach et al., 1996). The three scales of EE, DP and PA have coefficient alphas of .90, .79, and .71 respectively. In Nigeria, Omoluabi (2000) reported an internal consistency of .86 and validity coefficients of .01 to .36 for the scale. The Cronbach alpha for the present study was .80 .

\section{Procedure}

Prior to the administration of the questionnaire to participants, one of the researchers visited the Ondo State Ministry of Culture and Tourism (with oversight function for hotels, parks, etc.) to collect data on registered hotels in the state. There were 25 registered hotels in the state at the time data for this study was collected. Armed with this information, the researchers approached the management of various hotels located within the study settings to solicit their cooperation for the study. Only 10 hotels agreed to cooperate. Prior to data gathering, all measures were approved by the personnel division in the participating hotels. After approval, the questionnaires with a cover letter explaining the study purpose and assurance of confidentiality were given to the hotel managers for distribution to all employees. The managers were also instructed to administer the questionnaires to workers who were willing to participate in the study under the condition of anonymity. A total of 300 questionnaires were distributed and 268 duly completed questionnaires were retrieved. This is a response rate of 89.3\%. Data collection spanned one month. After screening, all the retrieved questionnaires were found usable and were used for analysis.

\section{Data analysis}

Statistical analysis was conducted using IBM-SPSS Statistics for Windows, version 21. We first computed descriptive statistics to better understand the characteristics of the sample. Structural equation modelling was performed to test for the contribution of the predictors to the criterion through Analysis of Moment Structures (AMOS, version 21), using Maximum Likelihood (ML) estimation (Byrne, 2010).

\section{Results}

Correlation and structural equation techniques were conducted to examine the relationship between job burnout and various potential predictors. Table 2 presents the descriptive statistics and correlation results.

The results presented in Table 2 indicate a significant negative relationship between total burnout and POS $(r=-.36 ; p<.01)$. The correlation between total burnout and self-efficacy turned out to be significant $(r=-.33 ; p<.01)$. The correlations 
between POS, self-efficacy and total burnout indicate that the more employees perceive that the organisation cares about their well-being, and the more they believe in their personal abilities to handle job demands, the less their perception of burnout syndrome. A positive relationship was found between total burnout and age $(r=.16 ; p<.01)$. The three dimensions of burnout were significantly related to POS, self-efficacy and age. Emotional exhaustion $(r=-.40 ; p<.001)$, depersonalisation $(r=-.38 ; p<.001)$ and decreased personal accomplishment $(r=-.41 ; p<.001)$ were negatively related to POS. Self-efficacy was significantly and negatively related to emotional exhaustion $(r=-.24 ; p<.01)$, depersonalisation $(r=-.21 ; p<.01)$ and decreased personal accomplishment $(r=-.25 ; p<.01)$. Age was also significantly and positively correlated with emotional exhaustion $(r=.21 ; p<.001)$ and decreased personal accomplishment $(r=.15 ; p<.01)$.

The study hypothesis was that: (1) perceived organisational support, self-efficacy and age will independently contribute to total burnout and its three dimensions; and (2) perceived organisational support, self-efficacy and age will contribute jointly to total burnout and its three dimensions. Structural equation modelling techniques were conducted to identify the predictors of total burnout and its dimensions. The results are presented in Table 3 and Figure 1.

A path diagram is specified in AMOS version 21 to test the hypothesised relationships between the psychoorganisational variables and burnout, including its three dimensions of emotional exhaustion, depersonalisation and decreased personal accomplishment. The estimation of parameters in the model is measured using maximum likelihood estimation. Model fit indices, including chi squared $\left(\chi^{2}\right)$ test statistics or degrees of freedom $(d f)$ ratio, goodness-of-fit index (GFI), adjusted goodness-of-fit index
(AGFI), root mean square error of approximation (RMSEA), normed fit index (NFI), comparative fit index (CFI) and Tucker Lewis index (TLI), are taken into account to confirm the model fit to the data (Hu \& Bentler, 1999). In the present study, the measurement model of the three exogenous variables showed that the overall fit of the model was $\chi^{2}=411.681 ; p=<.001$.

Other indices of model fit were also used following the guidelines by Browne and Cudeck (1993), Byrne (2010), Hair, Black, Babin and Anderson (2010), Mak and Sockel Sockel (2001), (see also Vandenberg \& Scarpello (1994). Those scholars recommend at least one absolute fit index and one incremental fit index be used in addition to the $\chi^{2}$ statistic and the associated degree of freedom. Following this guideline, the CFI, GFI, AGFI, NFI, TLI, and RMSEA were adopted in estimating the model in addition to the $\chi^{2}$ statistic and the associated degree of freedom. However, observation of the indices of the model fit indicated that the three exogenous variables did not fit the data $(\mathrm{CFI}=0.940$; $\mathrm{RMSEA}=0.043$; $\mathrm{GFI}=0.864, \mathrm{AGFI}=-0.875, \mathrm{NFI}=0.841$, and $\mathrm{TLI}=-1.204)$.

On the basis of modification indices, the fit of the model can be improved by deleting age because of its lack of significant contribution to the model. We thereby obtained a revised model that postulates two exogenous variables (perceived organisational support and self-efficacy). These variables were fitted, and all indices met the criteria $\chi^{2}=417.398$, $p=<.001(\mathrm{CFI}=0.960 ;$ RMSEA $=0.075 ;$ GFI $=0.842$; AGFI $=0.925 ; \mathrm{NFI}=0.947$ and TLI $=0.961$ ). Accordingly, the fit indices presenting the overall fit of the model were encouraging as these values are within the threshold limits suggested in the SEM literature (e.g. Browne \& Cudeck, 1993; Byrne, 2010; Hair, Black, Babin \& Anderson, 2010; Mak \& Sockel, 2001; Vandenberg \& Scarpello, 1994).

TABLE 2: Correlation matrix $(r)$ of the latent variables $(n=268)$.

\begin{tabular}{|c|c|c|c|c|c|c|c|c|c|c|}
\hline Variables & M & SD & 1 & 2 & 3 & 4 & 5 & 6 & 7 & 8 \\
\hline 1. Total Burnout & 40.94 & 8.62 & 1 & - & - & - & - & - & - & - \\
\hline 2. Exhaustion & 22.32 & 5.04 & $.21^{* *}$ & 1 & - & - & - & - & - & - \\
\hline 3. Depersonalisation & 11.06 & 2.6 & $.16^{* *}$ & $.16^{* *}$ & 1 & - & - & - & - & - \\
\hline 4. Accomplishment & 18.49 & 3.54 & $.20 * *$ & $.16^{* *}$ & $.21^{* *}$ & 1 & - & - & - & - \\
\hline 5. POS & 41.08 & 11.05 & $-.36 * *$ & $-.40 * *$ & $-.38 * *$ & $-.41 * *$ & 1 & - & - & - \\
\hline 6. Self-efficacy & 30.1 & 4.72 & $-.33 * *$ & $-.24 * *$ & $-.21 * *$ & $-.25 * *$ & $.27^{* *}$ & 1 & - & - \\
\hline 7. Age & 29.66 & 6.53 & $.16^{* *}$ & $.21 * *$ & 0.01 & $15^{*}$ & -.07 & .02 & 1 & - \\
\hline 8. Length of service & 4.12 & 3.98 & 0.01 & 0.01 & 0.09 & .05 & .05 & -.02 & $.32 * *$ & 1 \\
\hline
\end{tabular}

POS, perceived organisational support

*, $p<0.05 ;{ }^{* *}, p<0.01$

TABLE 3: Results of structural equation modelling (SEM) estimates $(n=268)$.

\begin{tabular}{|c|c|c|c|c|c|c|}
\hline Variable & Parameter & Estimate & SE & CR & $p$ & Label \\
\hline Burnout & POS & -.290 & .045 & -5.063 & $* * *$ & - \\
\hline DEP & POS & -.348 & .014 & -5.963 & $* * *$ & - \\
\hline Burnout & SE & -.254 & .097 & -4.442 & $* * *$ & - \\
\hline EXH & POS & -.361 & .026 & -6.282 & $* * *$ & - \\
\hline DEP & SE & -.114 & .029 & -1.954 & .051 & - \\
\hline DPA & POS & -.361 & .018 & -6.291 & $* * *$ & - \\
\hline DPA & SE & -.149 & .039 & -2.600 & .009 & - \\
\hline
\end{tabular}

DEP, depersonalisation; EXH, emotional exhaustion; DPA, decreased personal accomplishment; SE, self-efficacy; POS, perceived organisational support. 


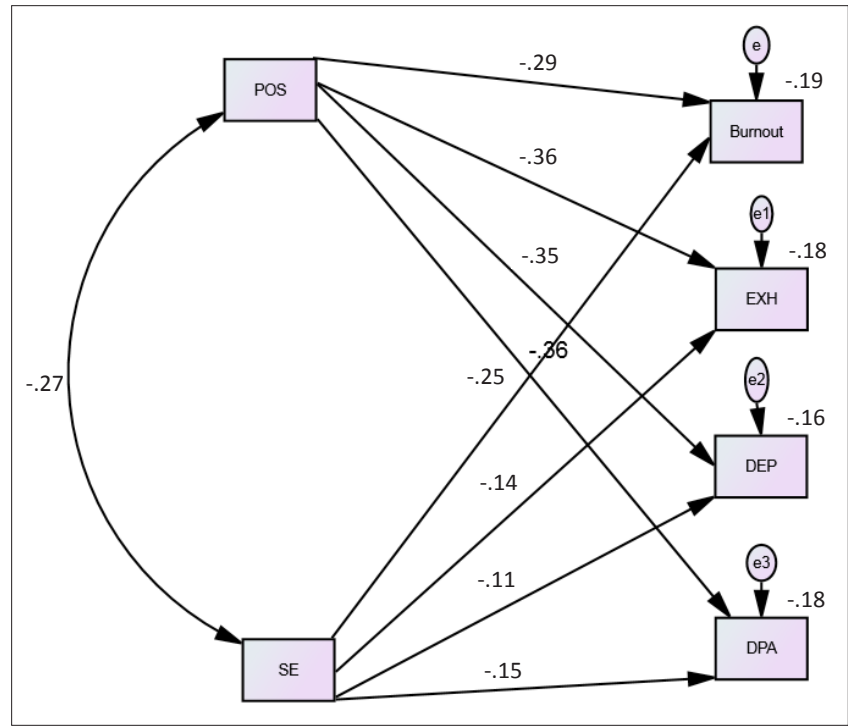

Source: Authors' field survey, 2012

DEP, depersonalisation; EXH, emotional exhaustion; DPA, decreased persona accomplishment; SE, self-efficacy; POS, perceived organisational support.

FIGURE 1: Paths between psycho-organisational variables and job burnout.

Figure 1 shows the standardised beta coefficients of the full model. Perceived organisational support significantly influences total burnout $(\beta=-.290 ; p<.001)$. Perceived organisational support is negatively related to depersonalisation $(\beta=-0.348 ; p<.001)$, emotional exhaustion $(\beta=-0.361, p<.001)$ and decreased personal accomplishment $(\beta=-0.361 ; p<.001)$. In the case of self-efficacy and total burnout, the direction of the beta value is negative $(\beta=-0.254$; $p<.001)$, indicating that decreased levels of self-efficacy are associated with an increased level of total burnout syndrome. The dimensions of depersonalisation $(\beta=-0.114 ; p<.001)$, emotional exhaustion $(\beta=-0.145 ; p<.001)$ and decreased personal accomplishment $(\beta=-0.149 ; p<.001)$ are found to have significant negative relationships with self-efficacy. As shown in Table 2 and Figure 1, Hypothesis 1 and Hypothesis 2 were partially supported.

\section{Discussion}

The aim of this study was to investigate the independent and joint influence of perceived organisational support, selfefficacy and ageonjobburnoutanditsdimensions. Thefindings revealed relationships between psycho-organisational factors (measured as perceived organisational support and selfefficacy) and total burnout and its dimensions. Our findings confirm that perceived organisational support, self-efficacy and age have significant joint influence on burnout and its dimensions. These results imply that favourable perception of organisational support, high self-efficacy and old age are indeed important psych-organisational resources that buffer hotel workers against job demands, and make them less vulnerable to burnout. Both perceived organisational support and self-efficacy are described as crucial factors in the burnout process (Humborstad et al., 2008; Jain \& Sinha, 2005; Kang et al., 2010; Skaalvik \& Skaalvik, 2007; Schaufeli \& Enzmann, 1998). This finding is in line with the prediction of the job resources aspect of the JD-R model and the postulations of COR theory concerning personal resources as psycho-organisational factors that protect employees against burnout (see Bakker \& Demerouti, 2007; Demerouti et al., 2001; Hobfoll, 1989).

Furthermore, perceived organisational support predicted total burnout and its dimensions. The implication of this is that organisations need to provide employees with the job resources, such as social support, to enable them to cope with job demands in order to be less susceptible to burnout. When employees know that help is available from the organisation during difficult times, they focus less on the environmental stressors, and are less vulnerable to burnout. The link between perceived organisational support and burnout concur with past studies (e.g. Bakker et al., 2004; De Beer et al., 2013; Hakanen et al., 2006; Lizano \& Mor Barak, 2012), and suggest that job resources such as organisational support and supervisory support are organisational resources from which employees can draw to cope with high job demands and be less at risk of burnout.

Self-efficacy contributed significantly to exhaustion and decreased personal accomplishment dimensions but not to total burnout and depersonalisation. Low self-efficacious individuals express self-doubt about their abilities to handle environmental demands; therefore, they become vulnerable to emotional exhaustion and erosion of their sense of effectiveness. Thus, increasing self-efficacy in workers may increase their personal resources to cope with problematic work situations, and by implication reduce their vulnerability to burnout. This finding is consistent with previous findings in this area (Caprara et al., 2003; Maslach et al., 2001; Schaufeli \& Enzmann, 1998; Skaalvik \& Skaalvik, 2007).

\section{Limitations of the study and suggestions for future research}

The present study has certain limitations. Firstly, the study is limited by its cross-sectional design. Future research should examine the relations of psycho-organisational variables and burnout over time in order to address issues of a causal relationship. Secondly, our study relied exclusively on selfreport measures. Future studies should include objective measures, such as behavioural indicators and physiological concomitants. In addition, future research should include other variables that can influence burnout (e.g. organisationbased self-esteem, optimism, hardy personality and emotional intelligence). It is also suggested that in the Nigerian context, future research should focus on the outcomes (e.g. ill health, psychological health, organisational commitment, turnover intention, etc.) of the relationships amongst job demands, job resources, personal resources, burnout and job engagement, adopting structural equation modelling techniques.

\section{Conclusion, recommendations, and implications for managers}

This study revealed that psycho-organisational factors predict burnout and its dimensions amongst hotel workers. 
These findings re-echo the relevance of both JD-R and COR theories in the development of burnout. In other words, job and personal resources are factors that buffer the effects of high job demands, and make employees less susceptible to job burnout. These findings point towards the impact of weak organisational support and low self-efficacy on vulnerability to job burnout. Although each of these variables has a different function in the burnout process, every one is relevant, and thus their joint consideration is important to reach a better explanation.

By implication, the findings suggest that JD-R and COR theories are relevant in the explanation of burnout. The practical implication is that when hotel managers provide the necessary organisational support for their employees, and employees have confidence in their abilities to handle work challenges, they are less likely to be susceptible to burnout. It is concluded that different stakeholders in the hotel industry in Nigeria and elsewhere who desire their employees' well-being and want to reduce the incidence of high job burnout amongst their workers should provide adequate organisational support to cope with difficult job demands and organise self-efficacy training to improve individuals' confidence in their abilities to deal with job burnout. Such intervention can be individual-orientated, organisation-oriented or a combination.

\section{Acknowledgements}

This work was conducted in partial fulfilment of the degree of B.Sc. Psychology at Adekunle Ajasin University, Akungba-Akoko, Ondo State, Nigeria. To all hotel managers and participants, who, despite the tight schedules, created the time to complete the research instruments and return them on time, we say thank you. We also acknowledge the useful suggestions made by the editor and the anonymous reviewers on the earlier drafts of this article.

\section{Competing interests}

The authors declare that they have no financial or personal relationship(s) that may have inappropriately influenced them in writing this article.

\section{Authors' contributions}

O.O. (North-West University \& Adekunle Ajasin University) was the project leader, drafted the manuscript and analysed the data. E.S.I. (North-West University) aided in the interpretation of the results and was involved in preparing the manuscript. A.O.O. (Adekunle Ajasin University) collected the data and was involved in the literature search. All authors have read and approved the final manuscript.

\section{References}

Adebayo, S.O., \& Ezeanya, I.D. (2011). Task identity and job autonomy as correlates of burnout among nurses in Jos, Nigeria. International Review of Social Sciences and Humanities, 2(1), 7-13. http://dx.doi.org/10.1108/02683940710733115

Babalola, S.S. (2009). Women entrepreneurial innovative behaviour: The role of psychological capital. International Journal of Business and Management, 4(11), 184-192.
Bakker, A.B., \& Demerouti, E. (2007). The job demands-resources model: State of the art. Journal of Managerial Psychology, 22, 309-328. http://dx.doi. org/10.1080/13594320344000165

Bakker, A.B., Demerouti, E., \& Schaufeli, W.B. (2003). Dual processes at work in a call centre: an application of the job demands-resources model. European Journal of Work and Organisational Psychology, 12(4), 393-417.

Bakker, A.B., Demerouti, E., \& Verbeke, W. (2004). Using the job demands-resources model to predict burnout and performance. Human Resource Management, 43, 83-104. http://dx.doi.org/10.1002/hrm.20004

Bandura, A. (1986). Social foundations of thought and action: A social cognitive theory. Englewood Cliffs, NJ: Prentice-Hall.

Bandura, A. (1997). Self-efficacy. The exercise of control. New York: Freeman.

Bitner, M.J., Booms, B.H., \& Mohr, L.A. (1994). Critical service encounters: the employee's viewpoint. Journal of Marketing, 58(4), 95-106. http://dx.doi. org/10.2307/1251919

Blunch, N.J. (2013). Introduction to structural equation modelling using IBM SPSS statistics and AMOS. (2nd edn.). New Delhi: Sage.

Brotheridge, C.M., \& Lee, R.T. (2005). Impact of work-family interference on general well-being: A replication and extension. International Journal of Stress Management, 12, 203-221. http://dx.doi.org/10.1037/1072-5245.12.3.203

Browne, M.W., \& Cudeck, R. (1993). Alternative ways of assessing model fit. In K.A. Bollen, \& J.S. Long (Eds.), Testing structural equation models (pp. 136-162) Newbury Park, CA: Sage.

Burisch, M. (2002). A longitudinal study of burnout: The relative importance of dispositions and experiences. Work \& Stress, 16, 1-17. http://dx.doi. org/10.1080/02678370110112506

Byrne, B.M. (2010). Structural equation modelling with AMOS; basic concepts, applications and programming. New York: Taylor and Francis Group, LLC.

Caprara, G.V., Barbaranelli, C., Borgogni, L., \& Steca, P. (2003). Efficacy beliefs as determinants of teachers' job satisfaction. Journal of Educational Psychology 95(4), 821-832. http://dx.doi.org/10.1037/0022-0663.95.4.821

Carlson, D.S., \& Perrewe, P.L. (1999). The role of social support in the stressor-strain relationship: An examination of work-family conflict. Journal of Management, 25 513-540. http://dx.doi.org/10.1177/014920639902500403

De Beer, L.T., Pienaar, J., \& Rothmann, S. Jr. (2013). Investigating the reversed causality of engagement and burnout in job demands-resources theory. SA Journal of Industrial Psychology, 39(1), 9 pages. http://dx.doi.org/10.4102/sajip.v39i1.1055

Demerouti, E., Bakker, A.B., Nachreiner, F., \& Schaufeli, W.B. (2001). The job demandsresources model of burnout. Journal of Applied Psychology, 86, 499-512. http:// dx.doi.org/10.1037/0021-9010.86.3.499

Dupre, K., \& Day, A. (2007). The effects of supportive management and job quality on the turnover intentions and health of military personnel. Human Resource Management, 46, 185-201. http://dx.doi.org/10.1002/hrm.20156

Eisenberger, R., Huntington, R., Hutchison, S., \& Sowa, D. (1986). Perceived organisational support. Journal of Applied Psychology, 71, 500-507. http://dx.doi. org/10.1037/0021-9010.71.3.500

Hair, J.F. Jr, Black, W.C., Babin, B.J., \& Anderson, R.E. (2010). Multivariate data analysis: A global perspective. (7th edn.). New Jersey: Pearson Education Inc. http://dx.doi. org/10.1016/j.jmva.2009.12.014

Hakenen, J.J., Bakker, A.B., \& Schaufeli, W.B. (2006). Burnout and work engagement among teachers. Journal of School Psychology, 43(6), 495-513. http://dx.doi. org/10.1016/j.jsp.2005.11.001

Heverling, M. (2011). Burnout prevalence and prevention in a state child welfare agency. Social Work Theses. Paper 69. Retrieved February 26, 2013, from http:// digitalcommons.providence.edu/socialwrk_students/69

Hobfoll, S.E. (1989). Conservation of resources. A new attempt at conceptualising stress. American Psychologist, 44(3), 513-24. http://dx.doi.org/10.1037/0003066X.44.3.513

Hobfoll, S.E. (2002). Social and psychological resources and adaptation. Review of General Psychology, 6(4), 307-324. http://dx.doi.org/10.1037/1089-2680.6.4.307

Hobfoll, S.E. \& Lilly R.S. (1993) Resource conservation as a strategy for community psychology. Kent State University. Journal of Community Psychology, 21,128-
$147 . \quad$ http://dx.doi.org/10.1002/1520-6629(199304)21:2\%3C128::AIDJCOP2290210206\%3E3.0.CO;2-5

Hu, L.T., \& Bentler, P.M. (1999).Evaluation model fit. In R.H. Hoyle (Ed.), Structura equation modelling: Concepts, issues, and applications (pp. 76-99). Thousand Oaks, CA: Sage.

Hughes, J.A. (1995). Measuring burnout among higher education faculty members in Alabama. Unpublished doctoral dissertation, Vanderbilt University, Nashville, United States of America.

Humborstad, S.I., Humborstad, B., \& Whitfield, R. (2008). Burnout and service employees' willingness to deliver quality service. Journal of Human Resource, Hospitality and Tourism, 7, 45-64. http://dx.doi.org/10.1300/J171v07n01_03

Jackson, S.E., Schwab, R.L., \& Schuler, R.S. (1986). Toward an understanding of the burnout phenomenon. Journal of Applied Psychology, 71, 630-640. http://dx.doi. org/10.1037/0021-9010.71.4.630

Jain, A.K., \& Sinha, A.K. (2005). General health in organisations: Relative relevance of emotional intelligence, trust, and organizational support. International Journal of Stress Management, 12, 257-273. http://dx.doi.org/10.1037/10725245.12.3.257 
Kang, B., Twigg, N.W., \& Hertzman, J. (2010). An examination of social support and social identity factors and their relationship to certified chefs' burnout International Journal of Hospitality Management, 29, 168-176. http://dx.doi. International Journal of Hospitalit
org/10.1016/j.ijhm.2009.08.004

Karatepe, O.M., \& Aleshinloye, K.D. (2009). Emotional dissonance and emotional exhaustion among hotel employees in Nigeria. International Journal of Hospitality Management, 28, 349-358. http://dx.doi.org/10.1016/j.ijhm.2008.12.002

Karatepe, O.M., \& Olugbade, O.A. (2009). The effects of job and personal resources on hotel employees' work engagement. International Journal of Hospitality Management, 28, 504-512. http://dx.doi.org/10.1016/j.ijhm.2009.02.003

Lazarus, R.S. (1991). Emotion and adaptation. New York: Oxford University Press.

Ledgerwood, C.R., Crotts, J.C., \& Everett, A.M. (1998). Antecedents of employees' burnout in the hotel industry. Progress in Tourism and Hospitality Research, 4(1), 31-44.

Lee, K.E. (2011). Moderating effects of leader-member exchange (LMX) on job burnout in dieticians and chefs of institutional foodservice. Nutrition Research and Practice, 5(1), 80-87. http://dx.doi.org/10.4162/nrp.2011.5.1.80, PMid:21487501

Lee, K.E., \& Shin, K.H. (2005). Job burnout, engagement and turnover intention of dieticians and chefs at a contract foodservice management company. Journal of Community Nutrition, 7, 100-106.

Leiter, M.P., Jackson, N.J., \& Shaughnessy, K. (2009). Contrasting burnout, turnover intention, control, value congruence and knowledge sharing between Baby Boomers and Generation X Journal of Nursing Management 17, 100-109. hab:// dx.doi.org/10.1111/j.1365-2834.2008.00884.x, PMid:19166528

Lizano, E.L., \& Mor Barak, M.E. (2012). Workplace demands and resources as antecedents of job burnout among public child welfare workers: A longitudinal study. Children and Youth Services Review, 34(9), 1769-1776. http://dx.doi. org/10.1016/j.childyouth.2012.02.006

Luszczynska, A., Scholz, U., \& Schwarzer, R. (2005). The general self-efficacy scale: Multicultural validation studies. The Journal of Psychology, 139(5), 439-457. http://dx.doi.org/10.3200/JRLP.139.5.439-457

Mak, B.L., \& Sockel, H. (2001). A confirmatory factor analysis of IS employee motivation and retention. Information \& Management, 38(5), 265-276. http:// dx.doi.org/10.1016/S0378-7206(00)00055-0

Maslach, C., \& Jackson, S.E. (1981). The measurement of experienced burnout. Journal of Organizational Behaviour, 2, 99-113. http://dx.doi.org/10.1002/ job.4030020205

Maslach, C., Jackson, S.E., \& Leiter, M.P. (1996). Maslach Burnout Inventory manual. (3rd edn.). Palo Alto, CA: Consulting Psychologists Press.

Maslach, C., Schaufeli, W.B, \& Leiter, M.P. (2001). Job burnout. Annual Review of Psychology, 52, 397-422. http://dx.doi.org/10.1146/annurev.psych.52.1.397, PMid:11148311

Melendez, W.A., \& deGuzman, R.M. (1983). Burnout: The New Academic Disease. ASHE-ERIC Higher Education Research Report No. 9. Washington, DC: Association for the Study of Higher Education.
Ojedokun, O. (2010). Customer-oriented behaviour of bank employees: Contributions of psycho-organisational variables and demographic factors. Envision: International Commerce and Management Journal, 2, 1-11.

Omoluabi, P.F. (2000). Maslach burnout inventory manual. Lagos: PPC Consultant.

O'Neil, J.W, \& Xiao, Q. (2010). Effects of organisational/occupational characteristics and personality traits on hotel manager emotional exhaustion. Internationa Journal of Hospitality Management, 29, 652-658. http://dx.doi.org/10.1016/j. ijhm.2009.12.004 Parasuraman, S., Greenhaus, J.H. \& Granrose, C.S. (1992), Role stressors, social
support, and well-being among two-career couples. Journal of Organisational Behaviour, 13, 339-356. http://dx.doi.org/10.1002/job.4030130403

Peiro, J.M. (1993). Descencadenantes del estres laboral [Work stressors]. Madrid: Eudema Psicologia.

Permanent Life Situation Survey. (2009). Heading for Burnout? Retrieved February 23, 2013, from http://www.adrenalfatigue.co.nz

Rhoades, L., \& Eisenberger, R. (2002). Perceived organizational support: A review of the literature. Journal of Applied Psychology, 87, 698-714. http://dx.doi. org/10.1037/0021-9010.87.4.698

Schaufeli, W.B., \& Enzmann, D. (1998). The burnout companion to study and practice A critical analysis. London: Taylor and Francis.

Schwarzer, R. (1992). Self-efficacy in the adoption and maintenance of health behaviours: Theoretical approaches and a new model. In R. Schwarzer (Ed.), Selfefficacy: Thought control of action (pp. 217-242). Washington, DC: Hemisphere. Schwarzer, R., \& Jerusalem, M. (1995). Generalized self-efficacy scale. In J. Weinman, S. Wright, \& M. Johnston (Eds.), Measures in health psychology: A user's portfolio (pp. 35-38). Windsor: NFER-Nelson.

Shore, L.M., \& Wayne, S.J. (1993). Commitment and employee behaviour: Comparison of affective commitment and continuance commitment with perceived organisational support. Journal of Applied Psychology, 78(5), 774-780. http:// dx.doi.org/10.1037/0021-9010.78.5.774, PMid:8253631

Skaalvik, E.M., \& Skaalvik, S. (2007). Dimensions of teacher self-efficacy and relations with strain factors, perceived collective teacher efficacy, and teacher burnout. Journal of Educational Psychology, 99, 611-625. http://dx.doi.org/10.1037/0022 0663.99.3.611

Thomas, C.H., \& Lankau, M.J. (2009). Preventing burnout: The effects of LMX and mentoring on socialisation, role stress, and burnout. Human Resource Management, 48, 417-432. http://dx.doi.org/10.1002/hrm.20288

Vandenberg, R.J., \& Scarpello, V. (1994). A longitudinal assessment of the determinant relationship between employee commitments to the occupation and the organization. Journal of Organizational Behaviour, 15 (6), 535-547. http://dx.doi. org/10.1002/job.4030150605

World Health Organization (WHO). (2010). International Classification of Diseases and Related Health Problems (10th revision). Retrieved June 6, 2013, from http:// www.who.int/classifications/icd/en/ 